\title{
Introduction: The Materiality of the Immaterial: ICTs and the Digital Commons
}

\author{
Andreas Roos, Vasilis Kostakis and Christos Giotitsas
}

\author{
Lund University, Lund, Sweden, roos.j.andreas@gmail.com \\ Tallinn University of Technology, Tallinn, Estonia, vasileios.kostakis@ttu.ee \\ University of Leicester, Leicester, United Kingdom, cg255@le.ac.uk
}

\begin{abstract}
Today, two great signs of change are occurring. On the one hand, the capitalist world economy is putting tremendous pressure on the earth's biosphere and bringing an onslaught of destruction to immediate environments and vulnerable people worldwide. On the other hand, the rise of new and progressive social-economic foundations is the result of an unprecedented increase of information and communication technologies (ICTs). Therefore it is arguably more crucial than ever to understand how social, economic and ecological foundations of the internet and ICT infrastructures are interwoven. What are we-as scholars, activists and citizens-to make of ICTs that seem to emerge from an economic and social system based upon ecological destruction and social oppression, while at the same time engaging millions of people in the proliferation of information, knowledge and active democratic collaboration? This special issue investigates how we can begin to understand this problem, and how we can hope to balance the perils and promises of ICTs in order to make way for a just and sustainable paradigm.
\end{abstract}

Keywords: Commons based peer production, peer-to-peer, political ecology, ICTs, materiality, immateriality, transition, sustainability, digital commons.

Recent studies by Christian Fuchs have examined the complex web of production relations and the new division of digital labour that makes possible the vast and cheap ICT infrastructure as we know it (Fuchs 2013; 2014). The analysis partly reveals that ICT products and infrastructure embody slave-like conditions that perpetually force mine and assembly workers into positions of dependency. Expanding this argument, the WWF has reported (Reed and Miranda 2007) that mining in the Congo basin poses considerable threats to the local environment in the form of pollution, loss of biodiversity, and an increased presence of businessas-usual made possible by roads and railways. This research highlights that ICTs are inherently material, as opposed to purely cognitive or code based, because the ICT infrastructure under the given economic structure embodies slave-like working conditions, various class relations and undesirable ecological consequences (see also Humphrey 2001). Thus, the position that views the emerging digital economy as purely immaterial is challenged.

At the same time, the emerging digital commons provide a new and promising platform for social developments, arguably enabled by the progressive dynamics of ICT development. These are predominantly manifested within commons-based peer production, i.e., a new mode of collaborative, social production (Benkler 2006); and grassroots desktop manufacturing or community-driven makerspaces, i.e. forms of bottom-up, distributed manufacturing. The most well-known examples of commons-based peer production are the free/open source software projects and the free encyclopaedia Wikipedia. While these novel forms of social organisation are immanent in capitalism, they also present the potential to challenge the dominant capitalist system of production and even transcend it (Kostakis and Bauwens 2014).

However, to view ICTs as being the cause for ecological destruction and social oppression while at the same time perceiving ICTs as a platform for social progression presents a paradox. How can something be at once oppressive and progressive? This question, we 
have discovered, is intimately linked to how ICTs are presented as "immaterial" contra "material" within different scientific discourses. So far, the perception of ICTs as immaterial (e.g. code, software, knowledge) sets one point of departure; whereas the understanding of ICTs as material (e.g. minerals, roads, satellites) sets another point of departure. Acknowledging that these two points of departure from which we understand ICTs are not necessarily distinct from one another, we present this special issue that seeks novel approaches to the concepts of im/materiality in order to dissolve and recreate some core understandings of ICTs and shed light on some of the most animate movements of our time.

Throughout this special issue the reader will encounter a variety of themes and approaches to the presented background. On the whole, we may identify three overarching subthemes.

The first stream of articles contributes to the growing position that peer production is not a form of organisation that is intrinsically beneficial for peers, citizens or users, but a mode of production permeated by political struggle and in need of further research and activism. Vasilis Niaros, in the article Introducing a Taxonomy of the "Smart City": Towards a Commonsoriented Approach?, presents this position by using as an example the concept of the "smart city". He concludes that different smart cities will likely create different forms of social and environmental effects depending on different models of technology governance. In a similar vein, J.Z. Garrod in The Real World of the Decentralized Autonomous Society argues that some peer-to-peer initiatives, such as Bitcoin 2.0 and its underlying neoliberal vision of freedom, may prove "a far more dystopian development than its supporters comprehend". In line with a similar reasoning, Arwid Lund and Juhana Venäläinen's Monetary Materialities of Peer-Produced Knowledge: The Case of Wikipedia and Its Tensions with Paid Labour investigates the internal tensions associated with un/paid editing work in the free encyclopaedia Wikipedia. Here, Lund And Venäläinen raise and discuss important key questions on how Wikipedia as a commons based peer production initiative manifests and responds to ever increasing commercial pressures characteristic of the capitalist economy.

The next two articles focus on the material infrastructure of ICTs. By examining urbanization, ICTs, and the emerging presence of new energy intensive industries in Oregon, Dillon Mahmoudi and Anthony Levenda's Beyond the Screen: Uneven Geographies, Digital Labour, and the City of Cognitive-Cultural Capitalist claim that digital labour is something that should be understood as reaching "beyond the screen", or, outside the immaterial, in the recirculation of capital. Similarly, Sibo Chen, in the article The Materialist Circuits and the Quest for Environmental Justice in ICT's Global Expansion emphasises the material realities of the ICT infrastructure as both an issue of labour and ecology. He brings perspectives from the field of environmental justice in understanding how global inequalities are in some ways intrinsic to ICTs and consumer electronics in the modern world economy.

Finally, the last two articles deal with issues concerning property regimes. In the article Commons, Piracy and the Crisis of Property, James Arvanitakis and Martin Fredriksson ponder whether digital piracy is "merely an act of individual gain or a response to the enclosure of neoliberal private property rights". They state that the act of piracy exposes a weakness in the logic of enclosure; be it piracy in the mundane everyday life of the user, or piracy as an instrument of the revolutionary. Similarly, albeit with a focus on the ascending regime of "open source", Elsa Tsioumani, Mike Muzurakis, Yannis leropoulos and Asterios Tsioumanis, in their article Following the Open Source Trail Outside the Digital World: Open Source Applications in Agricultural Research and Development, explore whether ICTs can function as a tool for citizens to overcome the intellectual property rights of seeds held by powerful corporations and elaborates on how open source relates to food security.

On the whole, this special issue delivers an array of perspectives, yet commonalities can be found. One such commonality shows that the struggle for a free democratic internet is essentially one and the same as the struggle for labour justice and a healthy biosphere. The political struggle of the user is essentially the same as the political struggle of the farmer; the struggle for the code is the same as the struggle for the seed, and the struggle for digital commons the same as that of the natural commons. In the face of capitalism, the immanent expansion of markets, and increasing alienation, it is time to join causes, or rather, to locate 
the underlying common cause in order to progress towards a more mature vision of a future sustainable paradigm.

\section{References}

Benkler, Yochai. 2006. The Wealth of Networks: How Social Production Transforms Markets and Freedom. New Haven: Yale University Press.

Fuchs, Christian. 2014. Digital Labour and Karl Marx. New York: Routledge.

Fuchs, Christian. 2013. Theorising and Analysing Digital Labour: From Global Value Chains to Modes of Production. The Political Economy of Communication 1 (2): 3-27. http://www.polecom.org/index.php/polecom/article/view/19.

Humphrey, David. 2001. Mining in the Knowledge-based Economy. Minerals and Energy-Raw Materials Report 16 (3), 3-8.

Kostakis, Vasilis and Michel Bauwens. 2014. Network Society and Future Scenarios for a Collaborative Economy. Basingstoke, UK: Palgrave Macmillan.

Reed, Erik and Marta Miranda. 2007. Assessment of the Mining Sector and Infrastructure Development in the Congo basin Region. Washington DC: World Wildlife Fund, Macroeconomics for Sustainable Development Program Office, 27. http://awsassets.panda.org/downloads/congobasinmining.pdf

\section{About the authors}

\section{Andreas Roos}

Andreas Roos is a Lund University graduate actively engaged in research regarding environmental sustainability. He holds an MSc in Human Ecology and is a collaborator of the P2P Lab.

\section{Vasilis Kostakis}

Vasilis Kostakis is Senior Research Fellow at the Ragnar Nurkse School of Innovation and Governance, Tallinn University of Technology, Estonia. He is also founder of the P2P Lab and long-time collaborator of the P2P Foundation.

Chris Giotitsas

Chris Giotitsas is a PhD student at the school of management, University of Leicester, UK. He is also a research fellow at the P2P Lab. 